\title{
EFFECTS OF MANAGEMENT PRACTICES ON GRASSLAND BIRDS: SAVANNAH SPARROW
}

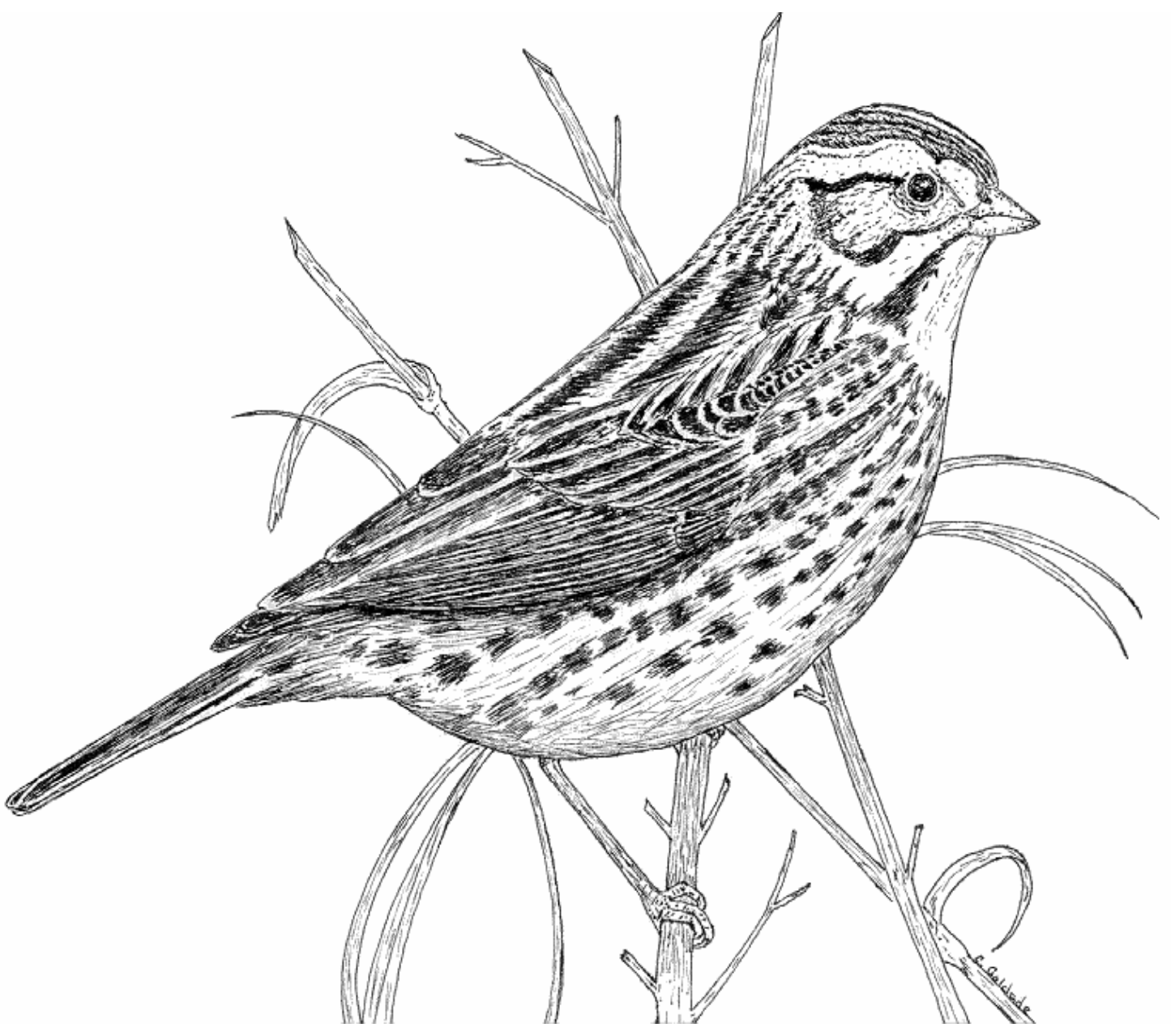

Grasslands Ecosystem Initiative

Northern Prairie Wildlife Research Center

U.S. Geological Survey

Jamestown, North Dakota 58401 
This report is one in a series of literature syntheses on North American grassland birds. The need for these reports was identified by the Prairie Pothole Joint Venture (PPJV), a part of the North American Waterfowl Management Plan. The PPJV recently adopted a new goal, to stabilize or increase populations of declining grassland- and wetland-associated wildlife species in the Prairie Pothole Region. To further that objective, it is essential to understand the habitat needs of birds other than waterfowl, and how management practices affect their habitats. The focus of these reports is on management of breeding habitat, particularly in the northern Great Plains.

Suggested citation:

Swanson, D.A. 1998 (revised 2002). Effects of management practices on grassland birds: Savannah Sparrow. Northern Prairie Wildlife Research Center, Jamestown, ND. 30 pages.

Species for which syntheses are available or are in preparation:

American Bittern

Mountain Plover

Marbled Godwit

Long-billed Curlew

Willet

Wilson's Phalarope

Upland Sandpiper

Greater Prairie-Chicken

Lesser Prairie-Chicken

Northern Harrier

Swainson's Hawk

Ferruginous Hawk

Short-eared Owl

Burrowing Owl

Horned Lark

Sedge Wren

Loggerhead Shrike

Sprague's Pipit
Grasshopper Sparrow

Baird's Sparrow

Henslow's Sparrow

Le Conte's Sparrow

Nelson's Sharp-tailed Sparrow

Vesper Sparrow

Savannah Sparrow

Lark Sparrow

Field Sparrow

Clay-colored Sparrow

Chestnut-collared Longspur

McCown's Longspur

Dickcissel

Lark Bunting

Bobolink

Eastern Meadowlark

Western Meadowlark

Brown-headed Cowbird 


\title{
EFFECTS OF MANAGEMENT PRACTICES ON GRASSLAND BIRDS:
}

\section{SAVANNAH SPARROW}

\author{
David A. Swanson
}

Series Coordinator: Douglas H. Johnson

Series Assistant Coordinator: Lawrence D. Igl

Reviewers: Nathaniel T.Wheelwright and Stephanie L. Jones

Range Map: Jeff T. Price

Cover Art: Christopher M. Goldade

Major Funding: Prairie Pothole Joint Venture, U.S. Fish and Wildlife Service U.S. Geological Survey

Funding also provided by: U.S. Forest Service

\section{Collaborators:}

Louis B. Best, Iowa State University

Carl E. Bock, University of Colorado

Brenda C. Dale, Canadian Wildlife Service

Stephen K. Davis, Saskatchewan Wetland Conservation Corporation James J. Dinsmore, Iowa State University

James K. Herkert, Illinois Endangered Species Protection Board

Fritz L. Knopf, Midcontinent Ecological Science Center

Rolf R. Koford, Iowa Cooperative Fish and Wildlife Research Unit

David R. C. Prescott, Alberta NAWMP Centre

Mark R. Ryan, University of Missouri

David W. Sample, Wisconsin Department of Natural Resources

David A. Swanson, Ohio Division of Wildlife

Peter D. Vickery, Massachusetts Audubon Society

John L. Zimmerman (retired), Kansas State University

March 1998

(revised January 2002) 


\section{ORGANIZATION AND FEATURES OF THIS SPECIES ACCOUNT}

Information on the habitat requirements and effects of habitat management on grassland birds were summarized from information in more than 4,000 published and unpublished papers. A range map is provided to indicate the relative densities of the species in North America, based on Breeding Bird Survey (BBS) data. Although birds frequently are observed outside the breeding range indicated, the maps are intended to show areas where managers might concentrate their attention. It may be ineffectual to manage habitat at a site for a species that rarely occurs in an area. The species account begins with a brief capsule statement, which provides the fundamental components or keys to management for the species. A section on breeding range outlines the current breeding distribution of the species in North America, including areas that could not be mapped using BBS data. The suitable habitat section describes the breeding habitat and occasionally microhabitat characteristics of the species, especially those habitats that occur in the Great Plains. Details on habitat and microhabitat requirements often provide clues to how a species will respond to a particular management practice. A table near the end of the account complements the section on suitable habitat, and lists the specific habitat characteristics for the species by individual studies. A special section on prey habitat is included for those predatory species that have more specific prey requirements. The area requirements section provides details on territory and home range sizes, minimum area requirements, and the effects of patch size, edges, and other landscape and habitat features on abundance and productivity. It may be futile to manage a small block of suitable habitat for a species that has minimum area requirements that are larger than the area being managed. The Brown-headed Cowbird (Molothrus ater) is an obligate brood parasite of many grassland birds. The section on cowbird brood parasitism summarizes rates of cowbird parasitism, host responses to parasitism, and factors that influence parasitism, such as nest concealment and host density. The impact of management depends, in part, upon a species' nesting phenology and biology. The section on breeding-season phenology and site fidelity includes details on spring arrival and fall departure for migratory populations in the Great Plains, peak breeding periods, the tendency to renest after nest failure or success, and the propensity to return to a previous breeding site. The duration and timing of breeding varies among regions and years. Species' response to management summarizes the current knowledge and major findings in the literature on the effects of different management practices on the species. The section on management recommendations complements the previous section and summarizes specific recommendations for habitat management provided in the literature. If management recommendations differ in different portions of the species' breeding range, recommendations are given separately by region. The literature cited contains references to published and unpublished literature on the management effects and habitat requirements of the species. This section is not meant to be a complete bibliography; a searchable, annotated bibliography of published and unpublished papers dealing with habitat needs of grassland birds and their responses to habitat management is posted at the Web site mentioned below.

This report has been downloaded from the Northern Prairie Wildlife Research Center WorldWide Web site, www.npwrc.usgs.gov/resource/literatr/grasbird/grasbird.htm. Please direct comments and suggestions to Douglas H. Johnson, Northern Prairie Wildlife Research Center, U.S. Geological Survey, 8711 37th Street SE, Jamestown, North Dakota 58401; telephone: 701253-5539; fax: 701-253-5553; e-mail: Douglas_H_Johnson@usgs.gov. 


\section{SAVANNAH SPARROW}

(Passerculus sandwichensis)

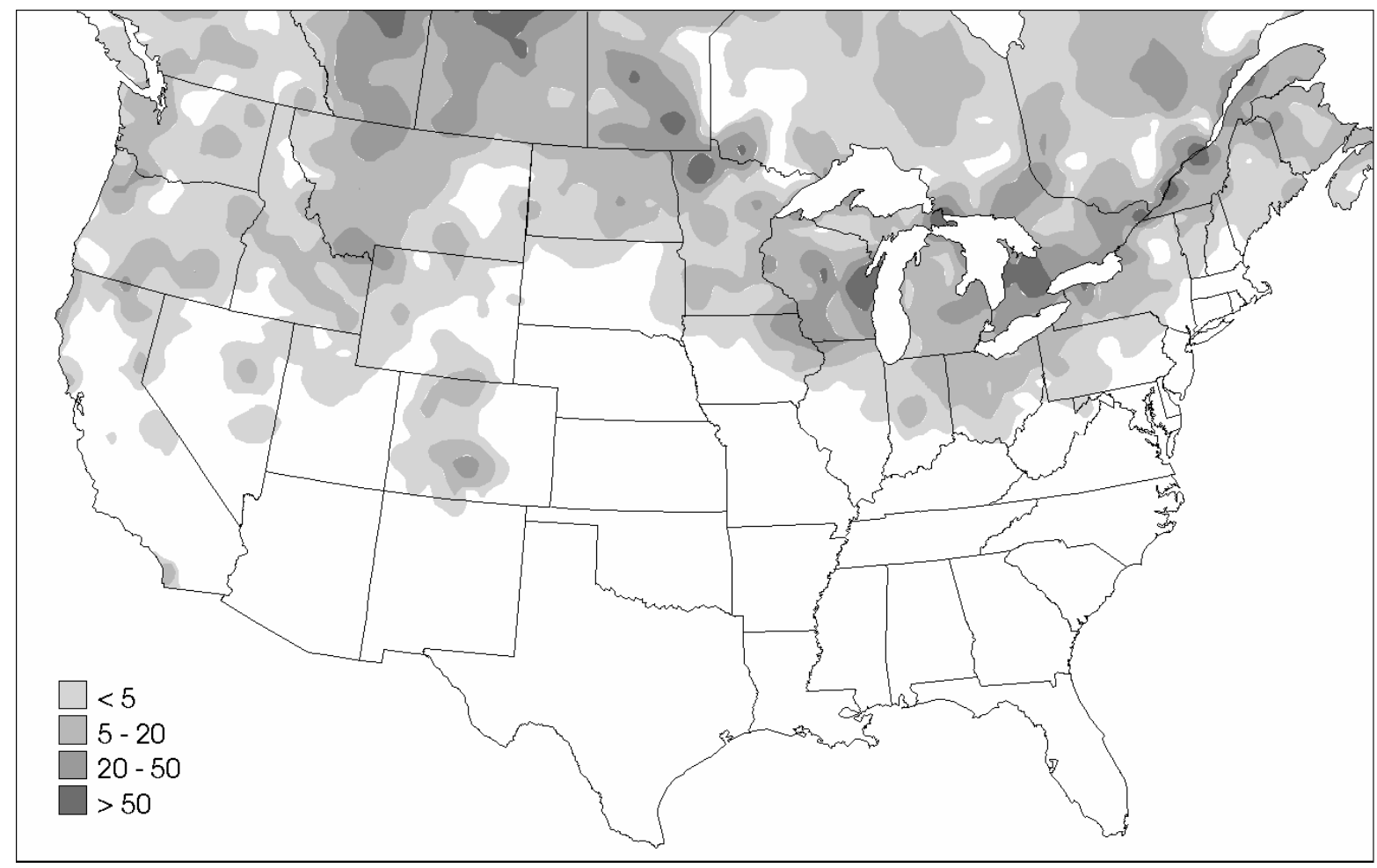

Figure. Breeding distribution of the Savannah Sparrow in the United States and southern Canada, based on Breeding Bird Survey data, 1985-1991. Scale represents average number of individuals detected per route per year. Map from Price, J., S. Droege, and A. Price. 1995. The summer atlas of North American birds. Academic Press, London, England. 364 pages.

Keys to management are providing large areas of suitable habitat (grasslands of intermediate height and density, with well-developed litter), controlling succession, and protecting nesting habitat from disturbance during the breeding season.

\section{Breeding range:}

Savannah Sparrows breed across Alaska and most of continental Canada, south to southern California, eastern Arizona, New Mexico, and Nebraska, and east through Missouri, West Virginia, and Nova Scotia (National Geographic Society 1987). (See figure for the relative densities of Savannah Sparrows in the United States and southern Canada, based on Breeding Bird Survey data.)

\section{Suitable habitat:}

Savannah Sparrows prefer habitats with short to intermediate vegetation height, intermediate vegetation density, and a well developed litter layer. These preferred habitats cover a wide range of vegetation types, including alpine and arctic tundra, coastal salt marshes, sedge bogs, grassy meadows, and native prairie (Wheelwright and Rising 1993). In North American grasslands, Savannah Sparrows occupy tallgrass prairie, idle and lightly grazed mixed-grass 
prairie, shortgrass, tame pastures, wet-meadow zones surrounding prairie wetlands, alfalfa (Medicago sativa)/brome (Bromus) hayfields, native and tame dense nesting cover (DNC), Conservation Reserve Program (CRP) lands, weedy crop and stubble fields, retired cropland, and wheat fields (Rand 1948; Harrison 1974; Stewart 1975; Salt and Salt 1976; Renken 1983; Dale 1993; Hartley 1994; Johnson and Igl 1995; Prescott et al. 1995; Skeel et al. 1995; Patterson and Best 1996; Prescott and Murphy 1996, 1999; Koford 1999; Horn and Koford 2000). In Colorado, Bock et al. (1999) compared the abundance of Savannah Sparrows between upland (mixed-grass prairie) and lowland (tallgrass prairie or tame hayland) grasslands. Savannah Sparrows were significantly more abundant on lowland than on upland plots. Although Savannah Sparrows occasionally breed in cropland, they are more abundant in idle native, DNC, and Conservation Reserve Program lands (Hartley 1994, Johnson and Igl 1995, Patterson and Best 1996). In Alberta, Manitoba, and Saskatchewan, Savannah Sparrows were more common in grasslands enrolled in the Permanent Cover Program (PCP) than in cropland (McMaster and Davis 1998). PCP was a Canadian program that paid farmers to seed highly erodible land to perennial cover; it differed from CRP in that haying and grazing were allowed annually in PCP. In Illinois, Savannah Sparrows were found in mixed and pure stands of hay, pastures, and idle grasslands, but reached highest densities in pastures and idle grasslands (Graber and Graber 1963).

In Wisconsin, Savannah Sparrow abundance was positively correlated to percent herbaceous vegetation cover (Sample 1989, Swanson et al. 1997), whereas in Ohio, abundance was negatively correlated to percent herbaceous vegetation cover. In North Dakota and Saskatchewan, Savannah Sparrow abundance was positively correlated with percent grass cover (Renken 1983, Renken and Dinsmore 1987, Sutter 1996). However, at a less arid site in Saskatchewan, Savannah Sparrow abundance was negatively correlated to percent grass cover (Sutter 1996). Within grazed mixed-grass areas in North Dakota, abundance of Savannah Sparrows was positively associated with percent grass cover, litter depth, visual obstruction (vegetation height/density), density of low-growing shrubs (western snowberry [Symphoricarpos occidentalis] and silverberry [Elaeagnus commutata]), vegetation density, and plant communities dominated by Kentucky bluegrass (Poa pratensis) and native grass (Stipa, Bouteloua, Koeleria, and Schizachyrium) (Schneider 1998). Abundance was negatively associated with percent clubmoss (Selaginella densa) cover and plant communities dominated by native grass. Strongest vegetational predictors of the presence of Savannah Sparrow were decreasing clubmoss cover, increasing grass cover, increasing litter depth, and decreasing visual obstruction. Savannah Sparrows were most abundant on Conservation Reserve Program fields with high percent grass and low percent legume cover in the northern Great Plains (Johnson and Schwartz 1993). Within cropland in southcentral Alberta, Savannah Sparrow abundance and productivity were negatively related to percent bare ground and positively related to litter depth (Martin and Forsyth 2003). In Oregon and Nevada, Rotenberry and Wiens (1980) found a positive correlation between Savannah Sparrow abundance and percent forb cover. In Wisconsin, Savannah Sparrow abundance was negatively correlated to maximum vegetation height and vegetation height/density (Sample 1989).

Wiens $(1969,1973)$ stated that Savannah Sparrows required low, dense vegetation for nest sites; grass-dominated habitats with little forb cover are preferred (Wiens 1969, 1973; Welsh 1975; Knight 1989; Vickery et al. 1992). In Wisconsin, Savannah Sparrows avoided habitats with tall, dense vegetation and nested primarily in managed or disturbed habitats such as 
pastures and hayfields (Sample 1989). In Michigan, Savannah Sparrows nested in hayfields of clover (Melilotis and Trifolium spp.), alfalfa, brome, and timothy (Phleum pratense), and in clumps of grass near cow pies in an overgrazed pasture (George 1952). In Maine, Savannah Sparrows nesting in areas of mainly forb and shrub cover experienced lower reproductive success than those nesting in predominantly grass cover (Vickery et al. 1992). In Quebec, vegetation height did not differ between Savannah Sparrow nest sites and random points, but successful nests were surrounded by taller vegetation than unsuccessful nests (Bedard and LaPointe 1984a).

Savannah Sparrows avoided areas with extensive tree cover (Wheelwright and Rising 1993). Wiens (1969) and O’Leary and Nyberg (2000) noted that most Savannah Sparrow breeding territories were located in the center of grassland habitats, away from cultivated fields and fence lines, and Sample (1989) found a negative correlation between Savannah Sparrow abundance and percent shrub cover. In North Dakota, Savannah Sparrows were found only on shrubless transects (Arnold and Higgins 1986). In Wyoming sagebrush steppe, Savannah Sparrows were observed only on burned and herbicide-treated areas with fewer shrubs and more grass and forb cover (Kerley and Anderson 1995). However, in West Virginia, Savannah Sparrows often included small trees, shrubs, and fence posts within the nesting territory (Shields 1935). In Saskatchewan, Savannah Sparrows nested in or near clumps of sparse western snowberry shrubs (Lein 1968). Savannah Sparrows in eastcentral Saskatchewan were associated with fallow fields that were in close proximity to a wetland and that had song perches on the edges of the fallow fields (Dale 1993). Although total woody cover in habitats used by Savannah Sparrows for nesting was low $(<1 \%)$, Sample (1989) reported that the birds often used small trees and shrubs ( $<2 \mathrm{~m}$ tall), fence posts and wire, and tall herbaceous stems as song perches. A table near the end of the account lists the specific habitat characteristics for Savannah Sparrows by study.

\section{Area requirements:}

Savannah Sparrow territories are small, ranging from 0.05 to 1.25 ha (George 1952, Lein 1968, Wiens 1969, Potter 1972, Welsh 1975, Piehler 1987, Wheelwright and Rising 1993, O'Leary and Nyberg 2000), and the species may occupy small ( $<5 \mathrm{ha}$ ) areas of suitable habitat (Potter 1972). However, based on data from Illinois, Herkert et al. (1993) categorized the Savannah Sparrow as highly sensitive to habitat fragmentation. Species with a high areasensitivity generally restrict nesting to large, contiguous habitats and rarely nest in small habitat fragments. In New York, Savannah Sparrow density was positively correlated with field size (Bollinger 1988, 1995), whereas in Saskatchewan, occurrence was negatively associated with area (SWCC 1997). In Illinois, Herkert $(1991 a, b, c)$ found no Savannah Sparrows on grassland tracts $<10$ ha and noted that they were significantly more likely to occur on large than small grasslands. Savannah Sparrow incidence increased with area and reached 50\% at about 10 ha in Maine (Vickery et al. 1994) and 40 ha in Illinois (Herkert 1994a).

In Minnesota tallgrass prairie, Savannah Sparrow abundance was higher, and nest depredation and Brown-headed Cowbird (Molothrus ater) brood parasitism rates lower, as distance to wooded edges increased; nest depredation rates were lower on large (130-486 ha) than small (16-32 ha) grassland fragments (Johnson and Temple 1986, 1990). In Saskatchewan, 700-1600 ha may be required to halve brood parasitism (SWCC 1997). In Colorado, Bock et al. (1999) compared the abundance of Savannah Sparrows between interior and edge locations. 
Edge was defined as the interface between suburban development and upland or lowland habitat, and interior locations were $200 \mathrm{~m}$ from edge. Savannah Sparrows were significantly more abundant on interior plots than on edge plots. In Illinois, Savannah Sparrows were more inclined to nest and hold territories in the interior of fields than in the $50 \mathrm{~m}$ between the interior of the field and the wooded boundary (O’Leary and Nyberg 2000).

Brown-headed Cowbird brood parasitism:

The Savannah Sparrow is a common host of the Brown-headed Cowbird (Friedmann et al. 1977). Parasitism rates vary from 2\% of 54 nests (Potter 1974) to 37\% of 46 nests (Johnson and Temple 1990). Refer to Table 1 in Shaffer et al. (2003) for rates of cowbird brood parasitism. Savannah Sparrows may be multiply-parasitized (Knapton 1979, SWCC 1997, Davis and Sealy 2000). In Manitoba, mean number of host young fledged from successful, unparasitized nests was significantly higher than from successful, parasitized nests; cowbird parasitism cost Savannah Sparrows 2.2 young/successful nest (Davis and Sealy 2000). In Saskatchewan, distance to cowbird perches and amount of concealment cover were not significantly different between parasitized and unparasitized nests (S. K. Davis, Saskatchewan Wetland Conservation Corporation, Regina, Saskatchewan, unpublished data).

Breeding-season phenology and site fidelity:

Savannah Sparrows arrive on the breeding grounds between late March and early May, and begin nesting in May (George 1952, Baird 1968, Lein 1968, Maher 1973, Harrison 1974, Welsh 1975, Knapton 1979, Bedard and LaPointe 1984b, Wheelwright and Rising 1993). In North Dakota, Savannah Sparrows breed from late May through late July, with peak breeding occurring from early June to mid-July (Stewart 1975). If the first nesting attempt fails, Savannah Sparrows will renest, and many females produce a second clutch after a successful first nest (George 1952; Lein 1968; Taber 1968; Wiens 1969; Harrison 1974; Weatherhead 1979; Wheelwright and Rising 1993; M. Winter and D. H. Johnson, unpublished data). In northern areas, Savannah Sparrows may be limited to a single brood (Maher 1973, Weatherhead 1979). In Saskatchewan, Savannah Sparrows departed from their breeding territories in early August, but remained in the area, foraging in weedy fields, along road edges, and along the margins of lakes and sloughs (Lein 1968). Fall migration occurs from mid-September to October (George 1952, Maher 1973, Knapton 1979).

In the Canadian Maritimes, male and female Savannah Sparrows are philopatric (Bedard and LaPointe 1984b, Wheelwright and Rising 1993). Philopatry to breeding territories in Newfoundland is high; 95\% of surviving males and 90\% of surviving females return to within 40 $\mathrm{m}$ of territories from a previous year (Wheelwright and Rising 1993). In Michigan, a banded adult was recaptured 6 yr later at the site where it was banded (Klimkiewicz and Futcher 1987). There is little information on Savannah Sparrow philopatry in the Great Plains, and philopatry of grassland birds in the Great Plains may be low (Wiens 1974, Johnson 1996). Of 169 Savannah Sparrows banded in Minnesota, ten males and six females returned the year following banding; both male and female members of four pairs returned (M. Winter and D. H. Johnson, unpublished data). Polygyny is common in populations residing in the Canadian Maritimes, but populations in other portions of the species range are generally monogamous (Welsh 1975, Wheelwright and Rising 1993). 
Species' response to management:

In Minnesota, Wisconsin, and South Dakota, higher densities of nesting Savannah Sparrows were found in unburned (for $\geq 12 \mathrm{mo}$ ) than burned grasslands (Tester and Marshall 1961, Martin 1967, Halvorsen and Anderson 1980, Huber and Steuter 1984). However, in eastcentral Wisconsin, highest densities occurred in recently burned restored tallgrass prairie (Volkert 1992). Halvorsen and Anderson (1980) attributed the difference in nesting densities between burned and unburned areas in central Wisconsin to the lack of litter, required by nesting Savannah Sparrows, in burned areas. In Minnesota, Savannah Sparrow abundance was significantly correlated with litter cover and litter depth, and may require $\geq 2$ yr of litter accumulation postfire before using a grassland for nesting (Tester and Marshall 1961). In North Dakota, Savannah Sparrows reached their highest densities 1-5 yr (Johnson 1997) and 6-8 yr postfire (Madden et al. 1999). Savannah Sparrows also were common on an idle control (Johnson 1997), and, although they reached their highest density 6-8 yr postfire, Savannah Sparrows exhibited no significant response to fire (Madden et al. 1999). Fire reduced Savannah Sparrow abundance for 3 yr postburn in a native grassland in Saskatchewan (Pylypec 1991). However, in Illinois, Savannah Sparrows preferred recently burned grassland for nesting (Herkert 1994a,b). Savannah Sparrow densities were highest in grasslands the first growing season postfire, lower on grasslands the second growing season postfire, and were not encountered $\geq 3$ growing seasons postfire (Herkert 1994a,b).

In Alberta, nesting densities of Savannah Sparrows were highest in undisturbed $(\geq 3$ growing seasons since last mowing) grasslands, but they also nested in grasslands that had been mowed the previous summer (Owens and Myres 1973). Also in Alberta, they preferred grasslands mowed after 15 July to haylands mowed before 15 July (Prescott et al. 1995). In Saskatchewan, Savannah Sparrows were more abundant in tame hayland idled for $\geq 3$ yr than in annually hayed tame vegetation or in idle native prairie (Dale 1992, Dale et al. 1997). In Manitoba, Savannah Sparrows were most abundant and most productive in hayland compared to native grassland, tame grasslands, and woodlands; productivity was evaluated using a behavioral index that ranked behavior indicative of nestling or fledgling care (Jones 1994). Savannah Sparrow abundance was highest in recently (within 4 mo of 1 May) mowed grasslands, which provided the low-to-medium vegetation height preferred by this species (Herkert 1991a). In North Dakota, Savannah Sparrows were significantly more abundant in the year after mowing in mowed portions of CRP fields than in idled portions (Horn and Koford 2000). In Michigan, Savannah Sparrow abundance was reduced after hayfields were mowed, and mowing exposed nests and young to predators (George 1952). In another Michigan study, Savannah Sparrows continued breeding following mowing in late June, but stopped breeding after the second mowing in early August (Harrison 1974). On seven rural Illinois airports, mowing destroyed $44 \%$ of all grassland bird nests, and Savannah Sparrow nest success was 23\% (Kershner and Bollinger 1996). In Canada, frequency of occurrence was higher in hayed PCP than in grazed PCP (McMaster and Davis 1998). In southern Saskatchewan hayfields, number of pairs was not affected by amount of cropland or wetland within $1.6 \mathrm{~km}$ of study areas (McMaster et al. 1999).

In short and mixed-grass prairie, moderately and heavily grazed areas do not provide the dense ground cover required by nesting Savannah Sparrows (Dale 1983). Several studies conducted in the Great Plains reported higher nesting densities of Savannah Sparrows on idle or lightly grazed grasslands compared to moderately or heavily grazed areas (Rand 1948; Owens and Myres 1973; Maher 1974,1979; Kantrud 1981; Kantrud and Kologiski 1982; Anstey et al. 
1995). For example, average breeding densities were 7.7 pairs/ha in ungrazed versus 0.3 pair/ha in grazed grasslands (Maher 1979). In southwestern Wisconsin, Savannah Sparrows were significantly more territorial in ungrazed grasslands than in rotationally or continuously grazed pastures (Temple et al. 1999). Nesting success was significantly higher on ungrazed grasslands than on continuously grazed grasslands and higher on continuously grazed grasslands than on rotationally grazed grasslands. Ungrazed grasslands and rotationally grazed pastures produced more young than continuously grazed pastures. Ungrazed grasslands were neither mowed or grazed from 15 May to 1 July. Continuously grazed sites were grazed throughout the summer at levels of 2.5- 4 animals/ha. Rotationally grazed pastures, stocked with 40-60 animals/ha, were grazed for 1-2 d and then left undisturbed for 10-15 d before being grazed again; pastures averaged 5 ha. All sites were composed of 50-75\% cool-season grasses, 7-27\% legumes, and 823\% forbs. In Tennessee, Savannah Sparrows no longer used a grassy field after it was heavily grazed (Knight 1989). In Idaho, Savannah Sparrows used both grazed and ungrazed riparian habitats, but were more abundant in ungrazed areas (Medin and Clary 1990).

Although heavily grazed areas are unsuitable for nesting, grazing can be used to improve habitat. In North Dakota, densities of Savannah Sparrows were highest in fields 1 yr postgrazing, followed by DNC, grazed, and idle fields (Renken 1983). In Saskatchewan, Savannah Sparrows foraged most frequently in grazed grasslands, but the number of nesting pairs was consistently lower in grazed than ungrazed areas (Dale 1984). Herkert et al. (1993) recommended light grazing, resulting in $\geq 40 \%$ vegetative cover $\geq 25 \mathrm{~cm}$ tall, to produce the intermediate vegetation height and density preferred by Savannah Sparrows. In Alberta, Savannah Sparrow frequency of occurrence did not significantly differ between four grazing treatments: early-season tame (grazed from late April to mid-June), early-season native (grazed in early summer), deferred-grazed native (grazed after 15 July), and continuously grazed native (Prescott and Wagner 1996). However, another study found that deferred tame pastures supported higher densities of Savannah Sparrows than deferred grazed mixed-grass or continuously grazed mixed-grass (Prescott et al. 1995). In North Dakota, Savannah Sparrow densities did not differ significantly between season-long (continuously grazed), short-duration, and twice-over rotation grazing treatments (Messmer 1990). Short-duration grazing involves a system of pastures rotated through a grazing schedule of about 1 wk grazed and 1 mo ungrazed, repeated throughout the season. Twice-over rotation involves grazing a number of pastures twice per season, with about a 2 mo rest in between grazing. Season-long grazing involves leaving a herd on the same pasture all season. Higher densities of Brown-headed Cowbirds were observed in summer-grazed versus winter-grazed pastures in Colorado, and Knopf et al. (1988) cautioned that summer grazing could lower reproductive success of Savannah Sparrows and other grassland-nesting birds.

In Saskatchewan, Savannah Sparrows were more abundant in hayland and tame pasture than in native pasture, and were detected least frequently in cropland (Anstey et al. 1995); in Alberta, the species also occurred more frequently in tame than native pasture (Prescott and Murphy 1996). In native pasture, the species preferred low to moderate cover diversity and moderate to tall grass; in tame pasture, the species preferred high herbaceous biomass (Prescott and Murphy 1996). However, another Saskatchewan study found that Savannah Sparrows occurred more frequently on native pasture than on pastures seeded to pure crested wheatgrass (Agropyron cristatum); no difference was found in Savannah Sparrow frequency of occurrence when native pastures were compared to pastures of crested wheatgrass/grass (smooth brome 
[Bromus inermus] and Kentucky bluegrass or crested wheatgrass/alfalfa (Davis and Duncan 1999). In Saskatchewan, Savannah Sparrows were common in both lightly grazed mixed-grass prairie and lightly grazed crested wheatgrass (Sutter and Brigham 1998). In prairie, numbers of Savannah Sparrows were positively related to grass, sedge, and litter cover; litter depth; and vertical vegetation density. Numbers of Savannah Sparrows were negatively correlated to forb density and bare ground. In crested wheatgrass, numbers of Savannah Sparrows were positively correlated to grass and sedge cover, maximum vegetation height, and litter depth.

Koford (1999) observed that in North Dakota, Savannah Sparrows were almost equally abundant in Waterfowl Production Areas (tracts of grassland and wetland managed by the U. S. Fish and Wildlife Service to provide nesting and brood-rearing habitat for waterfowl) as in CRP. In Minnesota, however, they were more abundant in Waterfowl Production Areas than in CRP. In eastcentral Saskatchewan, Savannah Sparrows were as common in fallow cropland as in two kinds of planted cover, that of DNC and low nesting cover (Dale 1993). However, Hartley (1994) found Savannah Sparrows in eastcentral Saskatchewan to be more common in DNC and native grasslands than in wheat fields. In Manitoba, Savannah Sparrows were as equally abundant in native DNC as in tame DNC and native grassland (Dhol et al. 1994). However, they were more productive in native DNC than in native grassland. Another Alberta study found that Savannah Sparrows were more abundant in tame DNC than in native DNC (Prescott et al. 1995).

In Alberta, Savannah Sparrow abundance and productivity increased when winter and spring wheat were managed with minimum-tillage practices rather than with conventionaltillage practices (Dale and McKeating 1996, Martin and Forsyth 2003). In Iowa, Savannah Sparrows nested at low densities in untilled fields of corn and soybeans that were idle in fall and spring and contained year-round crop residue, rather than in tilled fields (Basore et al. 1986). In another Iowa study, Savannah Sparrows were present in low numbers, and no nests were detected, in strip-intercropped fields (i.e., planting rowcrops, legumes, and small grains in a series of adjacent, narrow strips) (Stallman and Best 1996). In North Dakota, very few Savannah Sparrows were found nesting in any type of cropland (conventional tillage, minimum-tillage, and organic fields in fallow, sunflowers, or wheat) (Lokemoen and Beiser 1997). Minimum-tillage and organic fields had more vegetation and attracted greater numbers and species of birds, but predation and mechanical activities resulted in low reproductive success (Lokemoen and Beiser 1997). Conservation tillage (reduced and no-tillage) may create ecological traps, as grassland nesting birds are attracted to the habitat provided, but have low nesting success (Best 1986). In Saskatchewan, Savannah Sparrows were more abundant in DNC than in cropland on organic, conventional, or minimum-tillage farmland (Shutler et al. 2000). Presence of Savannah Sparrows was negatively related to amount of woody vegetation within $2.8 \mathrm{~km}^{2}$ of point counts. Savannah Sparrows were observed in wetlands or wetland margins within all farmland types and within DNC. Presence within wetlands was positively related to amount of water within wetlands and negatively related to water depth in late July, percent woody vegetation around wetland margin, and diversity of habitats around wetlands.

In Wyoming, mortality of Savannah Sparrows was observed after fenthion, a chemical used to control mosquitoes (Culicidae), was aerially applied at a rate of $47 \mathrm{~g} / \mathrm{ha}$ to an irrigated meadow (DeWeese et al. 1983). Fenthion is a cholinesterase inhibitor, and activity of brain cholinesterase was significantly lower for 5 d postspray in Savannah Sparrows collected from treated areas than in Savannah Sparrows from control areas. In Ontario corn fields, the mean 
number of Savannah Sparrows did not differ between pre- and post-applications of the granular insecticides fonofos and terbufos, which are used to control corn rootworm (Diabrotica spp.), or between treated fields and control fields (Knapton and Mineau 1995). In Maine, territory density of Savannah Sparrows decreased for 2-6 yr following the application of the herbicide hexazinone at a rate of $4 \mathrm{~kg} /$ ha on lowbush blueberries (Vaccinium angustifolium) (Vickery 1993).

In a Saskatchewan study that examined whether the abundance of grassland birds differed between roadsides and trailsides, abundance of Savannah Sparrows was significantly higher along roadsides than along trailsides (Sutter et al. 2000). Roads were defined as traveling surfaces with adjacent drainage ditches planted to smooth brome and ending with a fence 11-18 $\mathrm{m}$ from the traveling surface. Trails were defined as a single pair of wheel ruts visually indistinct from surrounding habitat in terms of plant structure and composition. Habitat along roads and trails were parcels of lightly to moderately grazed native prairie $>256$ ha.

\section{Management Recommendations:}

Promote management or enhancement activities that increase the amount of contiguous grassland habitat to benefit Savannah Sparrows (Herkert 1991a,c). Reduce amount of grassland edge near suburban interfaces (Bock et al. 1999). Remove woody vegetation within and along the periphery of grassland fragments to discourage predators that may use woody vegetation as travel corridors and to enlarge the amount of interior grassland (O’Leary and Nyberg 2000).

Acquire large grassland tracts and minimize edge effects through reduction of woody vegetation along edges and within grasslands (Wray et al. 1982; Johnson and Temple 1986, 1990; Burger et al. 1994). In small grasslands, adjacent woody habitats may allow edge and woodland predators to penetrate interior grassland areas.

Aim grassland restorations at benefitting bird species most sensitive to habitat fragmentation; restorations should be $\geq 50$ ha, preferably $>100$ ha (Herkert et al. 1993). Where grassland restorations $\geq 30$ ha are not possible, Herkert et al. (1993) recommended establishing several small grasslands, $6-8$ ha minimum size, within $0.4 \mathrm{~km}$ of each other, and using adjacent grassland habitats (e.g., pasture, hayland, waterway) as corridors among tracts.

Avoid disturbing (e.g., burning, mowing, moderate or heavy grazing) suitable habitat during the breeding season, approximately 1 May to 1 August. Treatments in nesting habitat should be delayed until after 1 August to prevent destruction of fledglings and renesting females (Swanson 1996).

Burn grasslands managed for breeding bird habitat in early spring (March to April) or late fall (October to November). In grasslands $\geq 50$ ha, burn $25-30 \%$ annually (Herkert et al. 1993). In mixed-grass prairie, burn every 5-7 yr (Madden et al. 1999).

When possible (e.g., on federal lands or through cooperation with private landowners), delay mowing of hayfields until mid-July, which would allow many birds to raise at least one brood in years with normal breeding phenology; mowing should be delayed further if nesting is delayed 
by inclement spring weather (Dale et al. 1997). When mowing must be done during the breeding season, divide large fields, mowing only half each year, or mow individual fields every other year to provide refuge for fledglings (Dale et al. 1997).

On airports not large enough to provide habitat for nesting birds (e.g., where all of the grassland available must be mowed to meet Federal Aviation Administration standards), mow grass short enough $(<4 \mathrm{~cm})$ to discourage nesting. This may cause birds to select alternative areas where nesting success would be higher (Kershner and Bollinger 1996).

Light grazing (leaving $\geq 40 \%$ vegetation cover $\geq 25 \mathrm{~cm}$ tall) can be used to create the intermediate vegetation height and density preferred by Savannah Sparrows (Herkert 1991a). 
Table. Savannah Sparrow habitat characteristics.

\begin{tabular}{|c|c|c|c|}
\hline Author(s) & Location(s) & Habitat(s) Studied* & Species-specific Habitat Characteristics \\
\hline Anstey et al. 1995 & Saskatchewan & $\begin{array}{l}\text { Cropland, mixed- } \\
\text { grass pasture, tame } \\
\text { hayland, tame } \\
\text { pasture }\end{array}$ & $\begin{array}{l}\text { Abundance was positively associated with dead vegetation 20- } \\
100 \mathrm{~cm} \text { tall and negatively associated with distance to nearest } \\
\text { shrub; favored lightly grazed pastures over moderately or } \\
\text { heavily grazed pastures }\end{array}$ \\
\hline Basore et al. 1986 & Iowa & Cropland, idle & Nested in low densities in corn planted into sod residue \\
\hline $\begin{array}{l}\text { Bedard and LaPointe } \\
1984 a\end{array}$ & Quebec & Idle tame, wetland & $\begin{array}{l}\text { Preferred open ground and avoided dense vegetation; successful } \\
\text { nests were surrounded by taller vegetation than unsuccessful } \\
\text { nests }\end{array}$ \\
\hline Bock et al. 1999 & Colorado & $\begin{array}{l}\text { Idle mixed-grass, } \\
\text { idle tallgrass, } \\
\text { mixed-grass pasture, } \\
\text { tallgrass pasture, } \\
\text { tame hayland }\end{array}$ & $\begin{array}{l}\text { Were more abundant on interior plots than on edge plots and in } \\
\text { lowland habitat than in upland habitat; edge was defined as the } \\
\text { interface between suburban development and upland or lowland } \\
\text { habitat, and interior locations were } 200 \text { m from edge; upland } \\
\text { grasslands were mixed-grass prairie and lowland grasslands } \\
\text { were tallgrass prairie or tame hayland }\end{array}$ \\
\hline Bollinger 1988 & New York & Tame hayland & $\begin{array}{l}\text { Density was positively correlated with field size and negatively } \\
\text { correlated with total percent grass and percent of field bordered } \\
\text { by woods; occupied fields had mean vegetation measurements } \\
\text { of } 23.9 \% \text { grass cover and } 26.3 \mathrm{~cm} \text { vegetation height }\end{array}$ \\
\hline Dale 1984 & Saskatchewan & $\begin{array}{l}\text { Idle mixed-grass, } \\
\text { mixed-grass pasture }\end{array}$ & $\begin{array}{l}\text { Used cultivated grasses; abundance was lower on grazed than on } \\
\text { ungrazed plots during dry summers; occupied areas had greater } \\
\text { forb height (mean height of } 7.4 \mathrm{~cm} \text { ), denser vegetation }<10 \mathrm{~cm} \text {, } \\
\text { and lower distance to nearest forb than unoccupied areas }\end{array}$ \\
\hline Dale 1992 & Saskatchewan & $\begin{array}{l}\text { Idle native, idle } \\
\text { native/tame, tame } \\
\text { hayland }\end{array}$ & $\begin{array}{l}\text { Were most abundant in tame hayfield mowed only during } \\
\text { drought (mowed once in } \geq 3 \mathrm{yr} \text { ); were also abundant in idle } \\
\text { native and idle native/tame grassland; were least abundant in }\end{array}$ \\
\hline
\end{tabular}




\begin{tabular}{|c|c|c|c|}
\hline & & & $\begin{array}{l}\text { annually hayed tame; abundance was positively correlated with } \\
\text { litter depth and negatively correlated with standing dead } \\
\text { vegetation }\end{array}$ \\
\hline Dale 1993 & Saskatchewan & $\begin{array}{l}\text { Dense nesting cover } \\
\text { (DNC; idle tame), } \\
\text { idle, low nesting } \\
\text { cover: idle tame }\end{array}$ & $\begin{array}{l}\text { Were associated with fallow fields adjacent to wetlands with } \\
\text { singing perches; were also common in DNC (tall wheatgrass } \\
\text { [Agropyron elongatum] and intermediate wheatgrass } \\
\text { [Agropyron intermedium]), alfalfa [Medicago sativa], and sweet } \\
\text { clover [Melilotus]) and low planted cover of creeping red fescue } \\
\text { (Festuca rubra) and Kentucky bluegrass (Poa pratensis) }\end{array}$ \\
\hline $\begin{array}{l}\text { Davis and Duncan } \\
1999\end{array}$ & Saskatchewan & $\begin{array}{l}\text { Mixed-grass } \\
\text { pasture, tame } \\
\text { pasture }\end{array}$ & $\begin{array}{l}\text { Were more frequent in native pastures than in pure crested } \\
\text { wheatgrass (Agropyron cristatum); occurrence was positively } \\
\text { associated with sedges (Carex spp.), alfalfa, standing dead } \\
\text { vegetation, and vegetation height }\end{array}$ \\
\hline Dhol et al. 1994 & Manitoba & $\begin{array}{l}\text { DNC (idle seeded- } \\
\text { native, idle tame), } \\
\text { idle mixed-grass }\end{array}$ & $\begin{array}{l}\text { Were equally abundant in native DNC (western wheatgrass } \\
\text { [Pascopyrum smithii], thick-spike wheatgrass [Agropyron } \\
\text { dasystachyum], slender wheatgrass [Agropyron caninum], green } \\
\text { needlegrass [Stipa viridula], big bluestem [Andropogon } \\
\text { gerardii], switchgrass [Panicum virgatum], and purple prairie } \\
\text { clover [Dalea purpurea]) as in tame DNC (tall wheatgrass, } \\
\text { intermediate wheatgrass, slender wheatgrass, and alfalfa) and } \\
\text { native grassland, but were more productive in native DNC than } \\
\text { in native grassland }\end{array}$ \\
\hline Dixon 1972 & $\begin{array}{l}\text { New } \\
\text { Brunswick }\end{array}$ & Idle tame & $\begin{array}{l}\text { Used cultivated grasses and bunch grasses of short to } \\
\text { intermediate height }\end{array}$ \\
\hline George 1952 & Michigan & $\begin{array}{l}\text { Cropland, hayland, } \\
\text { pasture, woodland } \\
\text { edge }\end{array}$ & Nested on the ground in clumps of herbaceous vegetation \\
\hline Graber and Graber & Illinois & Cropland, hayland, & Densities were higher in pasture and hayland than in cropland \\
\hline
\end{tabular}




\begin{tabular}{|c|c|c|c|}
\hline 1963 & & $\begin{array}{l}\text { idle, idle grassland, } \\
\text { tame pasture, } \\
\text { wetland, woodland }\end{array}$ & \\
\hline Harrison 1974 & Michigan & Tame hayland & $\begin{array}{l}\text { Preferred areas characterized by average vegetation } \\
\text { measurements of } 57.9 \% \text { litter cover, } 48.2 \mathrm{~cm} \text { vegetation height, } \\
4.8 \text { vegetation contacts/dm at } 5 \mathrm{~cm} \text { high, and } 13.1 \text { vegetation } \\
\text { contacts } / \mathrm{dm}^{2}\end{array}$ \\
\hline Hartley 1994 & Saskatchewan & $\begin{array}{l}\text { Cropland, DNC } \\
\text { (idle seeded-native, } \\
\text { idle seeded- } \\
\text { native/tame, idle } \\
\text { tame, idle tame } \\
\text { hayland), idle } \\
\text { mixed-grass }\end{array}$ & $\begin{array}{l}\text { Were present in DNC, idle native grasslands, and wheat fields; } \\
\text { more common in native grasslands and DNC }\end{array}$ \\
\hline Herkert $1994 b$ & Illinois & $\begin{array}{l}\text { Burned seeded- } \\
\text { native, burned } \\
\text { tallgrass }\end{array}$ & $\begin{array}{l}\text { Densities were highest on recently (within } 2 \text { growing seasons) } \\
\text { burned areas; were not encountered on areas the third or more } \\
\text { growing season postburn }\end{array}$ \\
\hline Horn and Koford 2000 & North Dakota & $\begin{array}{l}\text { CRP (idle tame, } \\
\text { tame hayland) }\end{array}$ & $\begin{array}{l}\text { Were significantly more abundant in the year after mowing in } \\
\text { mowed portions of CRP fields than in idled portions }\end{array}$ \\
\hline $\begin{array}{l}\text { Huber and Steuter } \\
1984\end{array}$ & South Dakota & $\begin{array}{l}\text { Burned mixed-grass } \\
\text { pasture, mixed-grass } \\
\text { pasture }\end{array}$ & $\begin{array}{l}\text { Higher densities were on unburned rather than burned } \\
\text { grasslands }\end{array}$ \\
\hline $\begin{array}{l}\text { Johnson and Schwartz } \\
1993\end{array}$ & $\begin{array}{l}\text { Minnesota, } \\
\text { Montana, } \\
\text { North Dakota, } \\
\text { South Dakota }\end{array}$ & $\begin{array}{l}\text { CRP (idle seeded- } \\
\text { native, idle tame), } \\
\text { cropland }\end{array}$ & $\begin{array}{l}\text { Were most abundant on CRP fields with high percent grass and } \\
\text { low percent legume cover }\end{array}$ \\
\hline Kantrud 1981 & North Dakota & Mixed-grass & Occurred in lightly grazed areas; lower densities were in \\
\hline
\end{tabular}




\begin{tabular}{|c|c|c|c|}
\hline & & $\begin{array}{l}\text { hayland, mixed- } \\
\text { grass pasture }\end{array}$ & moderately and heavily grazed areas \\
\hline $\begin{array}{l}\text { Kantrud and Kologiski } \\
1982\end{array}$ & $\begin{array}{l}\text { Colorado, } \\
\text { Montana, } \\
\text { Nebraska, } \\
\text { North Dakota, } \\
\text { South Dakota, } \\
\text { Wyoming }\end{array}$ & $\begin{array}{l}\text { Mixed-grass } \\
\text { pasture, shortgrass } \\
\text { pasture, shrubsteppe }\end{array}$ & $\begin{array}{l}\text { Densities were highest on lightly and moderately grazed pasture } \\
\text { on typic boroll soils; average vegetation height on this soil type } \\
\text { ranged from } 23 \text { to } 30 \mathrm{~cm} \text { and percent bare ground ranged from } 5 \\
\text { to } 8 \%\end{array}$ \\
\hline Knight 1989 & Tennessee & $\begin{array}{l}\text { Hayland, idle, } \\
\text { pasture }\end{array}$ & Used grass-dominated patches of a grass/forb pasture \\
\hline Knopf et al. 1988 & Colorado & $\begin{array}{l}\text { Riparian floodplain } \\
\text { pasture }\end{array}$ & $\begin{array}{l}\text { Used a winter- and summer-grazed willow (Salix) shrub } \\
\text { community in river floodplain }\end{array}$ \\
\hline Koford 1999 & $\begin{array}{l}\text { Minnesota, } \\
\text { North Dakota }\end{array}$ & $\begin{array}{l}\text { CRP (idle tame), } \\
\text { Waterfowl } \\
\text { Production Area } \\
\text { (WPA; burned, } \\
\text { hayland, idle native, } \\
\text { idle native/tame, } \\
\text { idle seeded-native, } \\
\text { idle tame) }\end{array}$ & $\begin{array}{l}\text { In North Dakota, were almost equally abundant in WPA as in } \\
\text { CRP; in Minnesota, were more abundant in WPA than in CRP }\end{array}$ \\
\hline $\begin{array}{l}\text { McMaster and Davis } \\
1998\end{array}$ & $\begin{array}{l}\text { Alberta, } \\
\text { Manitoba, } \\
\text { Saskatchewan }\end{array}$ & $\begin{array}{l}\text { Cropland; } \\
\text { Permanent Cover } \\
\text { Program (PCP; idle } \\
\text { tame, tame hayland, } \\
\text { tame pasture) }\end{array}$ & $\begin{array}{l}\text { Were more common in PCP than in cropland, and were more } \\
\text { common in PCP surrounded by grasslands than in PCP } \\
\text { surrounded by cropland, wetland, woodland, or human } \\
\text { residences; frequency of occurrence was higher in hayed PCP } \\
\text { than in grazed PCP }\end{array}$ \\
\hline McMaster et al. 1999 & Saskatchewan & $\begin{array}{l}\text { Hayland, PCP (tame } \\
\text { hayland) }\end{array}$ & $\begin{array}{l}\text { Amount of cropland or wetland within } 1.6 \mathrm{~km} \text { of study areas did } \\
\text { not affect number of indicated pairs }\end{array}$ \\
\hline
\end{tabular}




\begin{tabular}{|c|c|c|c|}
\hline $\begin{array}{l}\text { Owens and Myres } \\
1973\end{array}$ & Alberta & $\begin{array}{l}\text { Cropland, idle } \\
\text { mixed-grass, mixed- } \\
\text { grass hayland, } \\
\text { mixed-grass pasture }\end{array}$ & $\begin{array}{l}\text { Were equally abundant on an area of } 99 \% \text { native grassland and } \\
1 \% \text { cultivated land as on an area of } 66 \% \text { cultivated land, } 4 \% \\
\text { land seeded to exotic grasses, and } 30 \% \text { native grassland; nested } \\
\text { in undisturbed (unmowed } \geq 3 \mathrm{yr} \text { ), mowed, and grazed areas } \\
\text { dominated by rough fescue (Festuca scabrella); were not found } \\
\text { in areas of extensive cultivated land without rank vegetation at } \\
\text { field edges }\end{array}$ \\
\hline Piehler 1987 & Pennsylvania & Idle tame & $\begin{array}{l}\text { Occupied areas with mean vegetative characteristics of } 25.0 \% \\
\text { basal area cover, } 0.3 \% \text { shrub cover, } 34.9 \% \text { forb cover, } 75.2 \% \\
\text { litter cover, } 20.9 \% \text { bare ground cover, } 2.8 \mathrm{~cm} \text { litter depth, } 36.0 \\
\text { cm forb height, and } 84.4 \mathrm{~cm} \text { vegetation height }\end{array}$ \\
\hline $\begin{array}{l}\text { Prescott and Murphy } \\
1996\end{array}$ & Alberta & $\begin{array}{l}\text { Mixed-grass } \\
\text { pasture, tame } \\
\text { pasture }\end{array}$ & $\begin{array}{l}\text { Were more frequent on tame than native pasture. Preferred } \\
\text { native prairie with low to moderate cover diversity and moderate } \\
\text { to tall grass; preferred tame pasture with moderate amounts of } \\
\text { herbaceous biomass, moderate variation in herbaceous height, } \\
\text { and low proportion of forbs relative to grasses }\end{array}$ \\
\hline $\begin{array}{l}\text { Prescott and Murphy } \\
1999\end{array}$ & Alberta & $\begin{array}{l}\text { Cropland, DNC } \\
\text { (idle seeded- } \\
\text { native/tame) }\end{array}$ & $\begin{array}{l}\text { Were found in all age classes ( } 0-5 \text { yr) but were most abundant in } \\
1-3 \text { yr old DNC fields }\end{array}$ \\
\hline Prescott et al. 1995 & Alberta & $\begin{array}{l}\text { Cropland; DNC } \\
\text { (idle seeded-native, } \\
\text { idle tame), idle } \\
\text { mixed-grass, idle } \\
\text { parkland, idle tame, } \\
\text { mixed-grass pasture, } \\
\text { parkland pasture, } \\
\text { tame hayland, tame } \\
\text { pasture, wetland, } \\
\text { woodland }\end{array}$ & $\begin{array}{l}\text { Were abundant in deferred hayfields (mowed after } 15 \text { July) } \\
\text { followed by idle native grassland, tame DNC, and hayfields } \\
\text { mowed before } 15 \text { July; they also occurred in deferred tame } \\
\text { pastures, native DNC, continuously grazed native grassland, } \\
\text { deferred native pastures, idle tame grassland, tame pasture, } \\
\text { cropland, large ( }>8 \text { ha) saline wetlands, idle native parkland, } \\
\text { brush/shrub, large ( }>8 \text { ha) fresh wetlands, medium (1-8 ha) fresh } \\
\text { wetlands, medium ( } 1-8 \text { ha) saline wetlands, small ( }<8 \text { ha) saline } \\
\text { wetlands, shelterbelts, continuously grazed native parkland, and } \\
\text { small ( }<8 \text { ha) fresh wetlands }\end{array}$ \\
\hline
\end{tabular}




\begin{tabular}{|c|c|c|c|}
\hline Rand 1948 & Alberta & $\begin{array}{l}\text { Cropland, idle } \\
\text { shortgrass, } \\
\text { shortgrass pasture }\end{array}$ & $\begin{array}{l}\text { Were more common in low, damp areas with dense grass; were } \\
\text { found in the edges of ponds and marshes; were less common in } \\
\text { heavily grazed shortgrass prairie }\end{array}$ \\
\hline $\begin{array}{l}\text { Renken 1983, } \\
\text { Renken and Dinsmore } \\
1987\end{array}$ & North Dakota & $\begin{array}{l}\text { DNC (idle tame), } \\
\text { idle mixed-grass, } \\
\text { mixed-grass pasture }\end{array}$ & $\begin{array}{l}\text { Occupied areas with mean vegetation characteristics of } 66.1 \% \\
\text { grass cover, } 28.0 \% \text { forb cover, } 99.0 \% \text { litter cover, } 2.8 \% \text { shrub } \\
\text { cover, } 0.4 \% \text { bare ground, } 17 \mathrm{~cm} \text { effective vegetation height } \\
\text { (height of leaf cover), and } 2.8 \mathrm{~cm} \text { litter depth; abundance was } \\
\text { positively correlated to percent grass cover }\end{array}$ \\
\hline $\begin{array}{l}\text { Rotenberry and Wiens } \\
1980\end{array}$ & $\begin{array}{l}\text { Colorado, } \\
\text { Kansas, } \\
\text { Montana, } \\
\text { Nebraska, } \\
\text { Oklahoma, } \\
\text { Oregon, } \\
\text { South Dakota, } \\
\text { Texas, } \\
\text { Washington, } \\
\text { Wisconsin, } \\
\text { Wyoming }\end{array}$ & $\begin{array}{l}\text { Idle mixed-grass, } \\
\text { idle shortgrass, idle } \\
\text { shrubsteppe, idle } \\
\text { tallgrass, montane } \\
\text { meadow }\end{array}$ & Abundance was positively correlated to percent forb cover \\
\hline Sample 1989 & Wisconsin & $\begin{array}{l}\text { Burned tallgrass, } \\
\text { cropland, DNC (idle } \\
\text { seeded-native, idle } \\
\text { tame), idle, idle } \\
\text { seeded-native, idle } \\
\text { tallgrass, idle } \\
\text { tallgrass/tame, idle } \\
\text { tame, tame hayland, } \\
\text { tame pasture, tame } \\
\text { savanna pasture, wet } \\
\text { meadow, wet- }\end{array}$ & $\begin{array}{l}\text { Used areas with < } 1 \% \text { woody cover, } 75 \% \text { herbaceous cover, } 16 \% \\
\text { litter cover, } 9 \% \text { bare ground, } 54 \mathrm{~cm} \text { maximum vegetation height, } \\
\text { and } 17 \mathrm{~cm} \text { vegetation height/density; avoided habitats with the } \\
\text { tall, dense vegetation and used managed or disturbed habitats } \\
\text { with short, sparse vegetation; abundance was negatively } \\
\text { correlated to maximum vegetation height and vegetation } \\
\text { height/density }\end{array}$ \\
\hline
\end{tabular}




\begin{tabular}{|c|c|c|c|}
\hline & & meadow pasture & \\
\hline Schneider 1998 & North Dakota & $\begin{array}{l}\text { Mixed-grass } \\
\text { pasture, tame } \\
\text { pasture, wet- } \\
\text { meadow pasture }\end{array}$ & $\begin{array}{l}\text { Abundance was positively associated with percent grass cover, } \\
\text { litter depth, visual obstruction (vegetation height/density), } \\
\text { density of low-growing shrubs (western snowberry } \\
\text { [Symphoricarpos occidentalis] and silverberry [Elaeagnus } \\
\text { commutata]), vegetation density, and plant communities } \\
\text { dominated by Kentucky bluegrass and native grass (Stipa, } \\
\text { Bouteloua, Koeleria, and Schizachyrium); abundance was } \\
\text { negatively associated with percent clubmoss (Selaginella densa) } \\
\text { cover and plant communities dominated by native grass; } \\
\text { strongest vegetational predictors of the presence of Savannah } \\
\text { Sparrow were decreasing clubmoss cover, increasing grass } \\
\text { cover, increasing litter depth, and decreasing visual obstruction }\end{array}$ \\
\hline Shields 1935 & West Virginia & Idle tame & Preferred to place nests within clumps or patches of grasses \\
\hline Shutler et al. 2000 & Saskatchewan & $\begin{array}{l}\text { Cropland, DNC } \\
\text { (idle seeded-native, } \\
\text { idle seeded-tame), } \\
\text { wetland }\end{array}$ & $\begin{array}{l}\text { Were more abundant in DNC than in cropland on organic, } \\
\text { conventional, or minimum-tillage farmland; presence within } \\
\text { uplands was negatively related to amount of woody vegetation } \\
\text { within } 2.8 \mathrm{~km}^{2} \text { of point counts; were observed in wetlands or } \\
\text { wetland margins within all farmland types and within DNC; } \\
\text { presence within wetlands was positively related to amount of } \\
\text { water within wetlands and negatively related to water depth in } \\
\text { late July, percent woody vegetation around wetland margin, and } \\
\text { diversity of habitats around wetlands }\end{array}$ \\
\hline Sutter 1996 & Saskatchewan & $\begin{array}{l}\text { Idle mixed-grass, } \\
\text { mixed-grass pasture, } \\
\text { tame pasture }\end{array}$ & $\begin{array}{l}\text { Within a moderately moist site with native prairie, abundance } \\
\text { was positively correlated with bare ground cover, maximum } \\
\text { height, and horizontal heterogeneity, and negatively correlated } \\
\text { with grass and sedge cover; within a more arid site with } \\
\text { introduced vegetation, abundance was positively correlated to } \\
\text { grass and sedge cover, maximum height and litter depth; within }\end{array}$ \\
\hline
\end{tabular}




\begin{tabular}{|c|c|c|c|}
\hline & & & $\begin{array}{l}\text { a more arid site with native vegetation, abundance was } \\
\text { positively correlated with litter cover, litter depth, grass and } \\
\text { sedge cover, and negatively correlated with bare ground cover } \\
\text { and forb density }\end{array}$ \\
\hline $\begin{array}{l}\text { Sutter and Brigham } \\
1998\end{array}$ & Saskatchewan & $\begin{array}{l}\text { Mixed-grass } \\
\text { pasture, tame } \\
\text { pasture }\end{array}$ & $\begin{array}{l}\text { Were common in both lightly grazed mixed-grass prairie and } \\
\text { lightly grazed crested wheatgrass habitats; in prairie, numbers of } \\
\text { Savannah Sparrows were positively related to grass, sedge, and } \\
\text { litter cover; litter depth; and vertical vegetation density; } \\
\text { numbers were negatively correlated to forb density and bare } \\
\text { ground; in crested wheatgrass, numbers of Savannah Sparrows } \\
\text { were positively correlated to grass and sedge cover, maximum } \\
\text { vegetation height, and litter depth }\end{array}$ \\
\hline Sutter et al. 2000 & Saskatchewan & Mixed-grass pasture & $\begin{array}{l}\text { Abundance in mixed-grass prairie was twice as high along } \\
\text { roadsides than along trailsides }\end{array}$ \\
\hline Swanson et al. 1997 & Ohio & CRP (idle tame) & $\begin{array}{l}\text { Abundance was negatively correlated to percent herbaceous } \\
\text { vegetation cover }\end{array}$ \\
\hline $\begin{array}{l}\text { Tester and Marshall } \\
1961\end{array}$ & Minnesota & $\begin{array}{l}\text { Burned tallgrass, } \\
\text { idle tallgrass, } \\
\text { tallgrass hayland, } \\
\text { tallgrass pasture }\end{array}$ & $\begin{array}{l}\text { Abundance was significantly correlated to litter cover and litter } \\
\text { depth }\end{array}$ \\
\hline Vickery et al. 1992 & Maine & Idle tame & $\begin{array}{l}\text { Reproductive success was lower in areas with high forb and } \\
\text { shrub cover than in areas of predominantly grass cover }\end{array}$ \\
\hline Weatherhead 1979 & Manitoba & $\begin{array}{l}\text { Willow (Salix spp.) } \\
\text { shrub }\end{array}$ & $\begin{array}{l}\text { Used tall }(\geq 0.5 \mathrm{~m}) \text { and short }(<0.5 \mathrm{~m}) \text { willow habitat for nesting; } \\
\text { nest success was greater in short gray willow (Salix } \\
\text { brachycarpa) }\end{array}$ \\
\hline Welsh 1975 & Nova Scotia & Idle & $\begin{array}{l}\text { Nested in clumps of myrtle (Myrica pennsylvanica), tufts of old } \\
\text { beach grass (Ammophila breviligulata), heavy crowberry }\end{array}$ \\
\hline
\end{tabular}




\begin{tabular}{|l|l|l|l|}
\hline & & & $\begin{array}{l}\text { (Empetrum nigrum) growth, and under large clumps of reindeer } \\
\text { moss (Cladonia spp.) }\end{array}$ \\
\hline Whitmore 1979 & West Virginia & Idle tame & $\begin{array}{l}\text { Territories upon spring arrival were characterized by mean } \\
\text { vegetation characteristics of 34\% basal area cover grass, 8\% } \\
\text { forb cover, 64\% litter cover, 15\% bare ground, } 1 \text { cm litter depth, } \\
8 \text { cm forb height, 25 cm effective vegetation height; territories } \\
\text { during peak breeding season were characterized by mean } \\
\text { vegetation characteristics of 9\% basal area cover grass, 13\% } \\
\text { forb cover, 71\% litter cover, 29\% bare ground, } 1 \text { cm litter depth, } \\
10 \text { cm forb height, and 66 cm effective vegetation height }\end{array}$ \\
\hline Wiens 1969, 1973 & Wisconsin & $\begin{array}{l}\text { Idle pasture, idle } \\
\text { tame, tame pasture }\end{array}$ & $\begin{array}{l}\text { Used areas with 98\% grass cover, 27\% forb cover, 2\% bare } \\
\text { ground, and 42\% effective cover }<5 \text { cm; preferred grass- } \\
\text { dominated habitats with little forb cover; of 35 territories, mean } \\
\text { distance from territory boundary to woods was 225 m, to fence } \\
\text { line was 49.4 m, and to cultivated field was 94 m; 43\% of } \\
\text { territories included posts, 38\% fence lines, 15\% wire bales or } \\
\text { tangles, and 8\% trees }\end{array}$ \\
\hline $\begin{array}{l}\text { Wilson and Belcher } \\
1989\end{array}$ & Manitoba & $\begin{array}{l}\text { Idle mixed-grass, } \\
\text { idle tame }\end{array}$ & $\begin{array}{l}\text { Abundance was positively correlated with native prairie and } \\
\text { negatively correlated with introduced vegetation }\end{array}$ \\
\hline
\end{tabular}

*In an effort to standardize terminology among studies, various descriptors were used to denote the management or type of habitat. "Idle" used as a modifier (e.g., idle tallgrass) denotes undisturbed or unmanaged (e.g., not burned, mowed, or grazed) areas. "Idle" by itself denotes unmanaged areas in which the plant species were not mentioned. Examples of "idle" habitats include weedy or fallow areas (e.g., oldfields), fencerows, grassed waterways, terraces, ditches, and road rights-of-way. "Tame" denotes introduced plant species (e.g., smooth brome [Bromus inermis]) that are not native to North American prairies. "Hayland" refers to any habitat that was mowed, regardless of whether the resulting cut vegetation was removed. "Burned" includes habitats that were burned intentionally or accidentally or those burned by natural forces (e.g., lightning). In situations where there are two or more descriptors (e.g., idle tame hayland), the first descriptor modifies the following descriptors. For example, idle tame hayland is habitat that is usually mowed annually but happened to be undisturbed during the year of the study. 


\section{LITERATURE CITED}

Anstey, D. A., S. K. Davis, D. C. Duncan, and M. Skeel. 1995. Distribution and habitat requirements of eight grassland songbird species in southern Saskatchewan. Saskatchewan Wetland Conservation Corporation, Regina, Saskatchewan. 11 pages.

Arnold, T. W., and K. F. Higgins. 1986. Effects of shrub coverages on birds of North Dakota mixed-grass prairies. Canadian Field-Naturalist 100:10-14.

Baird, J. 1968. Savannah Sparrow (Passerculus sandwichensis). Pages 675-698 in Life histories of North American cardinals, grosbeaks, buntings, towhees, finches, sparrows, and allies, part two. Dover Publications, Inc., New York, New York.

Basore, N. S., L. B. Best, and J. B. Wooley. 1986. Bird nesting in Iowa no-tillage and tilled cropland. Journal of Wildlife Management 50:19-28.

Bedard, J., and G. LaPointe. 1984a. Banding returns, arrival times and site fidelity in the Savannah Sparrow (Passerculus sandwichensis). Wilson Bulletin 96:196-205.

Bedard, J., and G. LaPointe. 1984b. The Savannah Sparrow territorial system: can habitat features be related to breeding success? Canadian Journal of Zoology 62:1819-1828.

Best, L. B. 1986. Conservation tillage: ecological traps for nesting birds? Wildlife Society Bulletin 14:308-317.

Bock, C. E., J. H. Bock, and B. C. Bennett. 1999. Songbird abundance in grasslands at a suburban interface on the Colorado High Plains. Pages 131-136 in P. D. Vickery and J. R. Herkert, editors. Ecology and conservation of grassland birds of the Western Hemisphere. Studies in Avian Biology 19.

Bollinger, E. K. 1988. Breeding dispersion and reproductive success of Bobolinks in an agricultural landscape. Ph.D. dissertation. Cornell University, Ithaca, New York. 189 pages.

Bollinger, E. K. 1995. Successional changes and habitat selection in hayfield bird communities. Auk 112:720-730.

Burger, L. D., L. W. Burger, and J. Faaborg. 1994. Effects of prairie fragmentation on predation on artificial nests. Journal of Wildlife Management 58:249-254.

Dale, B. 1992. North American Waterfowl Management Plan implementation program related to non-game studies within the Prairie Habitat Joint Venture area, Annual report 19911992. Unpublished report. Canadian Wildlife Service, Saskatoon, Saskatchewan. 66 pages.

Dale, B. 1993. 1992 Saskatchewan non-game bird evaluation of North American Waterfowl Management Plan: DNC and short grass cover - 1992. Unpublished report. Canadian 
Wildlife Service, Edmonton, Alberta; Saskatchewan Wetland Conservation Corporation, Regina, Saskatchewan. 23 pages.

Dale, B. C. 1983. Habitat relationships of seven species of passerine birds at Last Mountain Lake, Saskatchewan. M.S. thesis. University of Regina, Regina, Saskatchewan. 119 pages.

Dale, B. C. 1984. Birds of grazed and ungrazed grasslands in Saskatchewan. Blue Jay 42:102105.

Dale, B. C., P. A. Martin, and P. S. Taylor. 1997. Effects of hay management on grassland songbirds in Saskatchewan. Wildlife Society Bulletin 25:616-626.

Dale, B. C., and G. McKeating. 1996. Finding common ground-the nongame evaluation of the North American Waterfowl Management Plan in Canada. Pages 258-265 in J. T. Ratti, editor. Proceedings of the seventh International Waterfowl Symposium.

Davis, S. K., and D. C. Duncan. 1999. Grassland songbird occurrence in native and crested wheatgrass pastures of southern Saskatchewan. Pages 211-218 in J. Herkert and P. Vickery, editors. Ecology and conservation of grassland birds of the Western Hemisphere. Studies in Avian Biology 19.

Davis, S. K., and S. G. Sealy. 2000. Cowbird parasitism and nest predation in fragmented grasslands of southwestern Manitoba. Pages 220-228 in J. N. M. Smith, T. L. Cook, S. I. Rothstein, S. K. Robinson, and S. G. Sealy, editors. Ecology and management of cowbirds and their hosts. University of Texas Press, Austin, Texas.

DeWeese, L. R., C. Lowell, L. A. S. McEwen, and R. D. Deblinger. 1983. Effects on birds of fenthion aerial application for mosquito control. Journal of Economic Entomology 76:906-911.

Dhol, S., J. Horton, and R. E. Jones. 1994. 1994 non-waterfowl evaluation of Manitoba’s North American Waterfowl Management Plan. Unpublished report. Wildlife Branch, Manitoba Department of Natural Resources, Winnipeg, Manitoba. 12 pages.

Dixon, C. L. 1972. A population study of Savannah Sparrows on Kent Island in the Bay of Fundy. Ph.D. thesis. University of Michigan, Ann Arbor, Michigan. 143 pages.

Friedmann, H., L. F. Kiff, and S. I. Rothstein. 1977. A further contribution to knowledge of the host relations of the parasitic cowbirds. Smithsonian Contributions to Zoology 235:1-75.

George, J. L. 1952. The birds on a southern Michigan farm. Ph.D. dissertation. University of Michigan, Ann Arbor, Michigan. 413 pages.

Graber, R. R., and J. W. Graber. 1963. A comparative study of bird populations in Illinois, 1906-1909 and 1956-1958. Illinois Natural History Survey Bulletin 28:383-528.

Halvorsen, H. H., and R. K. Anderson. 1983. Evaluation of grassland management for wildlife in central Wisconsin. Pages 267-279 in C. L. Kucera, editor. Proceedings of the Seventh 
North American Prairie Conference. Southwest Missouri State University, Springfield, Missouri.

Harrison, K. G. 1974. Aspects of habitat selection in grassland birds. M.S. thesis. Western Michigan University, Kalamazoo, Michigan. 82 pages.

Hartley, M. J. 1994. Passerine abundance and productivity indices in grasslands managed for waterfowl nesting cover in Saskatchewan, Canada. M.S. thesis. Louisiana State University, Baton Rouge, Louisiana. 42 pages.

Herkert, J. R. 1991a. An ecological study of the breeding birds of grassland habitats within Illinois. Ph.D. dissertation. University of Illinois, Urbana, Illinois. 112 pages.

Herkert, J. R. 1991b. Prairie birds of Illinois: population response to two centuries of habitat change. Illinois Natural History Survey Bulletin 34:393-399.

Herkert, J. R. 1991c. Study suggests increases in restored prairie fragments to conserve breeding bird communities. Restoration and Management Notes 9:107.

Herkert, J. R. 1994a. Breeding bird communities of midwestern prairie fragments: the effects of prescribed burning and habitat-area. Natural Areas Journal 14:128-135.

Herkert, J. R. 1994b. The effects of habitat fragmentation on midwestern grassland bird communities. Ecological Applications 4:461-471.

Herkert, J. R., R. E. Szafoni, V. M. Kleen, and J. E. Schwegman. 1993. Habitat establishment, enhancement and management for forest and grassland birds in Illinois. Illinois Department of Conservation, Division of Natural Heritage, Natural Heritage Technical Publication 1, Springfield, Illinois. 20 pages.

Horn, D. J., and R. R. Koford. 2000. Relation of grassland bird abundance to mowing of Conservation Reserve Program fields in North Dakota. Wildlife Society Bulletin 28:653659.

Huber, G. E., and A. A. Steuter. 1984. Vegetation profile and grassland bird response to spring burning. Prairie Naturalist 16:55-61.

Johnson, D. H. 1996. Management of northern prairies and wetlands for the conservation of Neotropical migratory birds. Pages 53-67 in F. R. Thompson, III, editor. Management of midwestern landscapes for the conservation of Neotropical migratory birds. U.S.D.A. Forest Service, General Technical Report NC-187.

Johnson, D. H. 1997. Effects of fire on bird populations in mixed-grass prairie. Pages 181-206 in F. L. Knopf and F. B. Samson, editors. Ecology and conservation of Great Plains vertebrates. Springer-Verlag, New York, New York.

Johnson, D. H., and L. D. Igl. 1995. Contributions of the Conservation Reserve Program to populations of breeding birds in North Dakota. Wilson Bulletin 107:709-718. 
Johnson, D. H., and M. D. Schwartz. 1993. The Conservation Reserve Program: habitat for grassland birds. Great Plains Research 3:273-295.

Johnson, R. G., and S. A. Temple. 1986. Assessing habitat quality for birds nesting in fragmented tallgrass prairies. Pages 245-249 in J. Verner, M. L. Morrison, and C. J. Ralph, editors. Wildlife 2000: modeling habitat relationships of terrestrial vertebrates. University of Wisconsin Press, Madison, Wisconsin.

Johnson, R. G., and S. A. Temple. 1990. Nest predation and brood parasitism of tallgrass prairie birds. Journal of Wildlife Management 54:106-111.

Jones, R. E. 1994. Non-waterfowl evaluation of Manitoba’s North American Waterfowl Management Program. Unpublished report. Wildlife Branch, Manitoba Department of Natural Resources, Winnipeg, Manitoba. 15 pages.

Kantrud, H. A. 1981. Grazing intensity effects on the breeding avifauna of North Dakota native grasslands. Canadian Field-Naturalist 95:404-417.

Kantrud, H. A., and R. L. Kologiski. 1982. Effects of soils and grazing on breeding birds of uncultivated upland grasslands of the northern Great Plains. U.S. Fish and Wildlife Service, Wildlife Research Report 15. 33 pages.

Kerley, L. L., and S. H. Anderson. 1995. Songbird responses to sagebrush removal in a high elevation sagebrush steppe ecosystem. Prairie Naturalist 27:129-146.

Kershner, E. L. 1995. Reproductive success of grassland birds at east-central Illinois Airports. M.S. thesis. Eastern Illinois University, Charleston, Illinois.

Klimkiewicz, M. K. and A. G. Futcher. 1987. Longevity records of North American birds: Coerebinae through Estrildidae. Journal of Field Ornithology 58:318-333.

Knapton, R. W. 1979. Birds of the Gainsborough-Lyleton region. Saskatchewan Natural History Society Special Publication 10. 72 pages.

Knapton, R. W., and P. Mineau. 1995. Effects of granular formulations of terbufos and fonofos applied to cornfields on mortality and reproductive success of songbirds. Ecotoxicology 4:138-153.

Knight, R. L. 1989. Second Tennessee breeding record of Savannah Sparrows, with comments on its expansion into the southern Appalachians. Migrant 60:69-71.

Knopf, F. L., J. A. Sedgwick, and R. W. Cannon. 1988. Guild structure of a riparian avifauna relative to seasonal cattle grazing. Journal of Wildlife Management 52:280-290.

Koford, R. R. 1999. Density and fledging success of grassland birds in Conservation Reserve Program fields in North Dakota and west-central Minnesota. Pages 187-195 in P. D. Vickery and J. R. Herkert, editors. Ecology and conservation of grassland birds of the Western Hemisphere. Studies in Avian Biology 19. 
Lein, R. 1968. The breeding biology of the Savannah Sparrow, Passerculus sandwichensis (Gmelin), at Saskatoon, Saskatchewan. M.S. thesis. University of Saskatchewan, Saskatoon, Saskatchewan.

Lokemoen, J. T., and J. A. Beiser. 1997. Bird use and nesting in conventional, minimumtillage, and organic cropland. Journal of Wildlife Management 61:644-655.

Madden, E. M., A. J. Hansen, and R. K. Murphy. 1999. Influence of prescribed fire history on habitat and abundance of passerine birds in northern mixed-grass prairie. Canadian Field-Naturalist 113:627-640.

Maher, W. J. 1973. Matador Project: Birds I. Population dynamics. Canadian Committee for the International Biological Programme, Matador Project, Technical Report 34. University of Saskatchewan, Saskatoon, Saskatchewan. 56 pages.

Maher, W. J. 1974. Matador Project: Birds II. Avifauna of the Matador area. Canadian Committee for the International Biological Programme, Matador Project, Technical Report 58. University of Saskatchewan, Saskatoon, Saskatchewan. 31 pages.

Maher, W. J. 1979. Nestling diets of prairie passerine birds at Matador, Saskatchewan, Canada. Ibis 121:437-452.

Martin, P. A., and D. J. Forsyth. 2003. Occurrence and productivity of songbirds in prairie farmland under conventional versus minimum tillage regimes. Agriculture Ecosystems and Environment 96:107-117.

Martin, S. G. 1967. Breeding biology of the Bobolink. M.S. thesis. University of Wisconsin, Madison, Wisconsin. 122 pages.

McMaster, D. G., and S. K. Davis. 1998. Non-game evaluation of the Permanent Cover Program. Unpublished report. Saskatchewan Wetland Conservation Corporation, Regina, Saskatchewan. $75+$ pages.

McMaster, D. G., J. H. Devries, and S. K. Davis. 1999. An integrated evaluation of cropland conversion in the Missouri Coteau of Saskatchewan: productivity of pintail and other grassland birds. Unpublished report. Saskatchewan Wetland Conservation Corporation, Regina, Saskatchewan; Institute for Wetland and Waterfowl Research, Oak Hammock Marsh, Manitoba; Ducks Unlimited Canada, Oak Hammock Marsh, Manitoba.

Medin, D. E., and W. P. Clary. 1990. Bird and small mammal populations in a grazed and ungrazed riparian habitat in Idaho. U.S.D.A. Forest Service, Res. Paper INT-425. Intermountain Research Station, Ogden, Utah.

Messmer, T. A. 1990. Influence of grazing treatments on nongame birds and vegetation structure in south central North Dakota. Ph.D. dissertation. North Dakota State University, Fargo, North Dakota. 164 pages. 
National Geographic Society. 1987. Field guide to the birds of North America, second edition. National Geographic Society, Washington, D.C. 464 pages.

O’Leary, C. H., and D. W. Nyberg. 2000. Treelines between fields reduce the density of grassland birds. Natural Areas Journal 20:243-249.

Owens, R. A., and M. T. Myres. 1973. Effects of agriculture upon populations of native passerine birds of an Alberta fescue grassland. Canadian Journal of Zoology 51:697-713.

Patterson, M. P., and L. B. Best. 1996. Bird abundance and nesting success in Iowa CRP fields: the importance of vegetation structure and composition. American Midland Naturalist 135:153-167.

Piehler, K. G. 1987. Habitat relationships of three grassland sparrow species on reclaimed surface mines in Pennsylvania. M.S. thesis. West Virginia University, Morgantown, West Virginia. 78 pages.

Potter, P. E. 1972. Territorial behavior in Savannah Sparrows in southeastern Michigan. Wilson Bulletin 84:48-59.

Potter, P. E. 1974. Breeding behavior of Savannah Sparrows in southeastern Michigan. JackPine Warbler 52:50-63.

Prescott, D. R. C., and A. Murphy. 1999. Bird populations in seeded nesting cover on North American Waterfowl Management Plan properties in the aspen parkland of Alberta. Pages 203-210 in P. D. Vickery and J. R. Herkert, editors. Ecology and conservation of grassland birds of the Western Hemisphere. Studies in Avian Biology 19.

Prescott, D. R. C., and A. J. Murphy. 1996. Habitat associations of grassland birds on native and tame pastures of the aspen parkland in Alberta. NAWMP-021. Alberta NAWMP Centre, Edmonton, Alberta. 36 pages.

Prescott, D. R. C., A. J. Murphy, and E. Ewaschuk. 1995. An avian community approach to determining biodiversity values of NAWMP habitats in the aspen parkland of Alberta. NAWMP-012. Alberta NAWMP Centre, Edmonton, Alberta. 58 pages.

Prescott, D. R. C., and G. M. Wagner. 1996. Avian responses to implementation of a complementary/rotational grazing system by the North American Waterfowl Management Plan in southern Alberta: the Medicine Wheel Project. NAWMP-018. Alberta NAWMP Centre, Edmonton, Alberta. 24 pages.

Pylypec, B. 1991. Impacts of fire on bird populations in a fescue prairie. Canadian FieldNaturalist 105:346-349.

Rand, A. L. 1948. Birds of southern Alberta. National Museum of Canada, Ottawa, Canada. Bulletin no. 111. Biological series, no. 37. 105 pages. 
Renken, R. B. 1983. Breeding bird communities and bird-habitat associations on North Dakota waterfowl production areas of three habitat types. M.S. thesis. Iowa State University, Ames, Iowa. 90 pages.

Renken, R. B., and J. J. Dinsmore. 1987. Nongame bird communities on managed grasslands in North Dakota. Canadian Field-Naturalist 101:551-557.

Rotenberry, J. T., and J. A. Wiens. 1980. Habitat structure, patchiness, and avian communities in North American steppe vegetation: a multivariate analysis. Ecology 61:1228-1250.

Salt, W. R., and J. R. Salt. 1976. The birds of Alberta. Hurtig Publishers, Edmonton, Alberta. 498 pages.

Sample, D. W. 1989. Grassland birds in southern Wisconsin: habitat preference, population trends, and response to land use changes. M.S. thesis. University of Wisconsin, Madison, Wisconsin. 588 pages.

Saskatchewan Wetland Conservation Corporation (SWCC). 1997. Grassland bird conservation through Saskatchewan's native prairie stewardship program. Saskatchewan Wetland Conservation Corporation, Regina, Saskatchewan. 25 pages.

Schneider, N. A. 1998. Passerine use of grasslands managed with two grazing regimes on the Missouri Coteau in North Dakota. M.S. thesis. South Dakota State University, Brookings, South Dakota. 94 pages.

Shaffer, J. A., C. M. Goldade, M. F. Dinkins, D. H. Johnson, L. D. Igl, and B. R. Euliss. 2003. Brown-headed Cowbirds in grasslands: their habitats, hosts, and response to management. Prairie Naturalist 35:146-186.

Shields, T. E. 1935. A study of the Savannah Sparrow in West Virginia. Wilson Bulletin 47:35-42.

Shutler, D., A. Mullie, and R. G. Clark. 2000. Bird communities of prairie uplands and wetlands in relation to farming practices in Saskatchewan. Conservation Biology $14: 1441-1451$.

Skeel, M. A., D. C. Duncan, and S. K. Davis. 1995. Abundance and distribution of Baird's sparrow in Saskatchewan in 1994. Saskatchewan Wetland Conservation Cooperation, Regina, Saskatchewan. 13+ pages.

Stallman, H. R., and L. B. Best. 1996. Bird use of an experimental strip intercropping system in northeast Iowa. Journal of Wildlife Management 60:354-362.

Stewart, R. E. 1975. Breeding birds of North Dakota. Tri-College Center for Environmental Studies, Fargo, North Dakota. 295 pages.

Sutter, G. C. 1996. Habitat selection and prairie drought in relation to grassland bird community structure and the nesting ecology of Sprague's Pipit, Anthus spragueii. Ph.D. thesis. University of Regina, Regina, Saskatchewan. 144 pages. 
Sutter, G. C., and R. M. Brigham. 1998. Avifaunal and habitat changes resulting from conversion of native prairie to crested wheat grass: patterns at songbird community and species levels. Canadian Journal of Zoology 76:869-875.

Sutter, G. C., S. K. Davis, and D. C. Duncan. 2000. Grassland songbird abundance along roads and trails in southern Saskatchewan. Journal of Field Ornithology 71:110-116.

Swanson, D. A. 1996. Nesting ecology and nesting habitat requirements of Ohio's grasslandnesting birds: A literature review. Ohio Fish and Wildlife Report 13. Division of Wildlife, Ohio Department of Natural Resources. 66 pages.

Swanson, D. A., D. P. Scott, and D. L. Risley. 1997. Wildlife benefits of the conservation reserve program in Ohio. unpublished report. Ohio Division of Wildlife, New Marshfield, Ohio.

Taber, W. 1968. Savannah Sparrow (Passerculus sandwichensis). Pages 698-725 in Life histories of North American cardinals, grosbeaks, buntings, towhees, finches, sparrows, and allies, part 2. Dover Publications, Inc., New York, New York.

Temple, S. A., B. M. Fevold, L. K. Paine, D. J. Undersander, and D. W. Sample. 1999. Nesting birds and grazing cattle: accommodating both on midwestern pastures. Pages 196-202 in P. D. Vickery and J. R. Herkert, editors. Ecology and conservation of grassland birds of the Western Hemisphere. Studies in Avian Biology 19.

Tester, J. R., and W. M. Marshall. 1961. A study of certain plant and animal interrelations on a native prairie in northwestern Minnesota. Minnesota Museum of Natural History, Occasional Papers 8:1-51.

Vickery, P. D. 1993. Habitat selection of grassland birds in Maine. Ph.D. dissertation. University of Maine, Orono, Maine. 124 pages.

Vickery, P. D., M. L. Hunter, and S. M. Melvin. 1994. Effects of habitat area on the distribution of grassland birds in Maine. Conservation Biology 8:1087-1097.

Vickery, P. D., M. L. Hunter, Jr., and J. V. Wells. 1992. Use of a new reproductive index to evaluate relationship between habitat quality and breeding success. Auk 109:697-705.

Volkert, W. K. 1992. Response of grassland birds to a large-scale prairie planting project. Passenger Pigeon 54:190-196.

Weatherhead, P. J. 1979. Ecological correlates of monogamy in tundra-breeding Savannah Sparrows. Auk 96:391-401.

Welsh, D. A. 1975. Savannah Sparrow breeding and territoriality on a Nova Scotia dune beach. Auk 92:235-251.

Wheelwright, N. T., and J. D. Rising. 1993. Savannah Sparrow (Passerculus sandwichensis). In A. Poole and F. Gill, editors. The birds of North America, No. 45. The Academy of 
Natural Sciences, Philadelphia, Pennsylvania; The American Ornithologists’ Union, Washington, D.C.

Whitmore, R. C. 1979. Temporal variation in the selected habitats of a guild of grassland sparrows. Wilson Bulletin 91:592-598.

Wiens, J. A. 1969. An approach to the study of ecological relationships among grassland birds. Ornithological Monographs 8:1-93.

Wiens, J. A. 1973. Interterritorial habitat variation in Grasshopper and Savannah Sparrows. Ecology 54:877-884.

Wiens, J. A. 1974. Climatic instability and the "ecological saturation" of bird communities in North American grasslands. Condor 76:385-400.

Wilson, S. D., and J. W. Belcher. 1989. Plant and bird communities of native prairie and introduced Eurasian vegetation in Manitoba, Canada. Conservation Biology 3:39-44.

Wray, T., II, K. A. Strait, and R. C. Whitmore. 1982. Reproductive success of grassland sparrows on a reclaimed surface mine in West Virginia. Auk 99:157-164. 